\title{
Exploring disruptions of the coloniality of knowledge, power and being to enable agency as disciplinary activists for curriculum change
}

\author{
Kasturi Behari-Leak (UCT) \\ Sisanda Nkoala (CPUT) \\ Goitsione Mokou (UCT) \\ Haaritha Binkowski (UWC) ${ }^{1}$
}

Journal of Decolonising Disciplines

Volume 2, Issue 2 (2020)

eISSN: 2664-3405

DOI: https://doi.org/10.35293/jdd.v2i2.25

\section{Abstract}

The \#RhodesMustFall (RMF) movement of 2015 and 2016 challenged universities across the nation to interrogate how their curriculum alienates and marginalises students, stymieing their success. Consequently, the HE sector has been challenged to respond to student calls for decolonisation by reviewing existing university curricula which promote forms of knowledge production that do not reflect an African worldview or a global South context. Academics have refocused their attention on exploring what an alternative, decolonial curriculum would entail. This paper reports on a professional development course, designed to support academics to 'decolonise their curricula', and explores what it meant to facilitate and participate in a course titled Understanding Coloniality. The paper asserts that one cannot embark on this work of transforming the curriculum without being disrupted oneself. Who we are as disciplinary experts in the university is socially interlinked with ways in which we have been 'disciplined' to think, be and do in specific ways; ways that do not necessarily enable epistemic and ontological access and freedom. Drawing on decolonial scholarship, the authors use auto-ethnography to engage with two disciplines, namely midwifery and journalism, to see how the metaphors of (de)coloniality surfaced in these disciplines and how they were mediated through a decolonial approach to course-design.

Keywords: decoloniality, coloniality, activism, agency.

1 In loving memory of our co-author Haaritha Binkowski who passed away on 24 July 2021. 


\section{Introduction}

The \#RhodesMustFall (RMF) movement, and collective student agency across the country, disrupted the traditional knowing and being of the university as we knew it (Mkhize 2015). The student protests of 2015 and 2016 challenged the academy and society to interrogate how hierarchies of power - implicit in the curriculum, pedagogy, assessment practices and epistemic choices - continue to be epistemically violent (Spivak 1994) and make students and academics (mainly black) feel alienated, marginalised and silenced (Kessi 2015; Maserumule 2015).

The call for decolonising the university is also about social justice that addresses the epistemic violence of colonial knowledge and colonial thought (Mbembe 2016; Pillay 2015). It stems from historical systems of marginalising, silencing and alienating forms of knowledge and practices that disadvantage the Other and reproduce ways of being that disempower the community it is mandated to serve (Maldonado-Torres 2016). The HE sector has also been challenged to respond to students' calls for decolonisation by reviewing existing university curricula which promote forms of knowledge production that do not reflect an African worldview or a global South context (Mampane, Omidire \& Aluko 2018). To this end, the main discourses in the national landscape that were strengthened post the \#RMF moment are associated with social justice, social inclusion and student success.

Decolonial action from the academy and the public (students, workers, academics and civil society) has prompted several institutional initiatives and responses through which faculties have been challenged to 'decolonise' their curricula and practices (Curriculum Change Working Group 2018). Academics have been tasked with interrogating how knowledge in their disciplines is constructed and legitimated in order to reproduce legacies of a colonial past. Faculties acknowledge a need for curriculum initiatives to integrate and incorporate gains made through the activism undertaken by students and staff. Currently, some universities, such as the University of Cape Town, Wits and Rhodes University, are focusing on decolonising teaching, curriculum design and assessment practices as a matter of urgency. Academics who are being encouraged to consider what decolonisation would mean for their own teaching, have signed up to professional development courses to help them to do this. Many professional development programmes have therefore refocused their attention on exploring what an alternative, decolonial curriculum for the different disciplines would entail. 


\section{Understanding the Understanding Decoloniality Course}

The Cape Higher Education Consortium (CHEC), which offers short courses for lecturers in the Western Cape to support their professional development, provided a unique opportunity for academics to explore and 'to come together in a relaxed and supportive atmosphere to learn, discuss and benefit from the valuable experiences of peers and expert facilitators from the four institutions' in the region (Cape Higher Education Consortium, 2019)

Among the CHEC offerings was the Understanding Decoloniality course in 2019 which brought together interested participants to co-create and develop an understanding of what it means to think, act and be, from a position of centredness and groundedness that is African. Through an understanding of how positionality and intersectionality shape our 'biographies and geographies' (Gordon 2019), the course was designed to explore alternative curricula, decolonial methodologies, pedagogical relations, knowledge construction and other modalities. The course was informed by a 'decolonial attitude' (Maldonado-Torres 2007) and a decolonial disposition to teaching and learning.

This course, designed to support academics to 'decolonise their curricula', engaged with participants to enhance their sense of knowing, being and doing by using a decolonial approach to teaching and learning. By modelling a decolonial pedagogy and epistemology, the facilitators encouraged course participants to apply their understanding (both embodied and conceptual) to the task of decolonising their courses and practices as university teachers and practitioners in higher education. The overall objective of the course was to develop a deeper understanding of the generative mechanisms that contribute to (un)transformed practices in different faculties; and to explore the capacity of academics and students to be key agents of change across the sector.

The course ran with 17 participants in attendance, two facilitators and two guest presenters. The participants, both emerging and established academics, came from a wide range of backgrounds, and sought to change or strengthen their thinking and practice by understanding decoloniality through dialogical thought and action. One of the first activities that introduced the course was one that asked participants to bring a physical object which embodied colonial thinking in their lives. For the final assessment, participants were asked to bring examples of projects, curricula, courses or ideas that they were in the process of re-shaping and re-framing using 
a decolonial approach. The facilitators/convenors of the course had both served on the Curriculum Change Working Group of a Western Cape University from 2016 to 2018, during the time of the student protests at one of the universities in the region.

The course ran over five weeks, with each session of a four-hour duration. Online support was provided in the interval between face-to-face sessions and assistance was provided individually in the development of the summative task. We also encouraged online forum discussions between sessions. A selection of relevant course readings was shared with participants by facilitators on the Learner Management System (LMS). The final assessment of the course required participants to create a proposal for a decolonised project related to the curriculum, pedagogy, assessments, research design or any other aspect that they chose to re-frame and that was relevant to their department, unit, faculty or university. This proposal was presented to the class and comprised the summative assessment for the course.

Although academics signed up for the CHEC course for different reasons (for some it was curiosity; for others it was a deep need to change existing practices), participants quickly saw that this course was not going to follow a lecture or seminarlike format typical of academic courses in HE. They were going to be challenged to bring the question of 'being' front and centre in the engagement. It also became evident that this course was a relational way to get a regional perspective on how decolonisation was being approached (if at all) at the four universities.

\section{Reflecting on the Understanding Coloniality course}

The following sections report on the Understanding Decoloniality course. This study focuses on the reflections of the participants and of the facilitators in relation to the development of proposals to decolonise their existing courses. These proposals served as site of critical thinking, reflection and disruption of current ways of knowing, power and being. These proposals have not yet been implemented, and as such the challenges of changing curricula coming out of these proposals can as yet only be envisioned rather than experienced. It is hoped that through offering these transformed courses, epistemic justice can be obtained in the fields of journalism and midwifery.

The research aim was to question how disruption, as a public-good imperative rather than a middle-class value, can serve as a catalyst for constructive social and academic change through the re-design of curricula. The research explores what it 
meant to facilitate and participate in this course by focusing on how academics and practitioners were themselves disrupted in the course of disrupting their practice. Importantly, the authors and participants of this research were all women of colour $\left(\right.$ Black $\left.^{2}\right)$, born in South Africa. Within the context of coloniality, they take up the position of "the other" (Said, 1978) and how they negotiate and disrupt structures (power, knowledge) rooted in coloniality by way of their agency is important to our discussion.

Through the lens of disruption, we focused on three metaphors of coloniality, namely knowledge, being and power, as advocated by decolonial scholars from Latin-America and the global South. By working theoretically and discursively through each of these metaphors, we engage with two disciplines, namely midwifery and journalism, which are the home-disciplines of two of the authors of this paper. Both midwifery and journalism offer extremely different perspectives in terms of knowledge and practice, which allowed us to see how the metaphors of coloniality surfaced in these two disciplines and how they were mediated through decolonial course re-design and re-imagination.

The foundations of traditional journalism in South Africa are steeped in colonial culture, in which the events that were considered to be news were those that served a predominantly white English- and Dutch-speaking audience (Tyali 2018). Even when African-language news publications were eventually printed some 60 year later, these were driven by missionaries and because of their reliance on white capital hindered them from providing an alternative and decolonial version of what journalism in this context could have been (Salawu 2013). The coloniality of the field of journalism is still very much in place in South African context since the way news is produced is still shaped by Western pluralistic values (Pitcher \& Jones 2018). Further English and Afrikaans media still dominate when it comes to the number of publications in these languages and the amount of advertising they are able to attract, even though audience-figures show that most South Africans prefer Nguni-language media (Finlay 2019). This points to a need to critique the current journalism curriculum at tertiary level since what students are taught in the classroom goes on to influence their practice in the field.

Similarly, midwifery in South Africa is deeply affected by colonialism. Due to

2 We use Black (emphasis on the uppercase) in the way the Steve Biko proposes referring to nonwhite populations working against the racist status quo. (Biko, 1978) 
midwifery being a female-dominated profession, its history can be framed only by the absences of these voices (Deacon 1998). Epistemicide of a profession is the epitome of colonial legacy. Historically, midwives were often represented poorly, as ill-trained, and of poor moral stature (Deacon 1998). By the early 1800s, men were responsible for asserting the 'clinical gaze', and through this lenstook over the right to women's birthing bodies, thus dominating the midwifery profession. By the early 1900s in the Cape, medical doctors had started to train midwives professionally, forming the structure of a subordinate, regulated profession completely separated from its traditional folk roots (Deacon 1998). This legacy, of midwifery being a subordinate profession to medicine and strictly regulated through medical doctors, continues today. The medicalisation of the profession has removed power from women and resulted in medical actions being done to women, rather than being a collaborative and empowering process. The being, knowledge and power of midwifery has irrevocably been changed and this highlights the need to engage with the discipline at the level of higher education, in order to address current colonial, gender and power inequalities.

By looking at 'disruption' through a pedagogy of activism and agency, we explore and assess the extent to which a professional development course designed to delink coursework, curriculum, pedagogy and being from their colonial trappings, achieves its aims. The paper highlights the need to disrupt the theory/practice divide by foregrounding praxis and asserting the importance of 'being.

\section{THEORETICAL FRAMING}

Colonisation around the world has left in its wake not only the physical manifestation of the maxim 'conquer and divide', but the mental, emotional and even ethereal wounds inflicted when people are minimised, negated and overpowered. The colonial scars are transferred intergenerationally, causing trauma and woundedness that are not easy to heal and repair. According to many decolonial scholars, the way to heal is through conscious and considered gestures and changes to the self. Such changes should entail first awakening oneself to one's own attitude and beliefs that have been shaped by colonisation, then to encourage others to do so as well, all the while using these shifts and insights to lead to change. From this perspective, understanding decoloniality is predicated on first understanding colonisation and 'coloniality' as mechanisms of oppression and inequality. 
According to Maldonado-Torres (2007), colonisation refers to the act of conquering and taking over a land that is not yours through a process that wipes out and annihilates traces of original ownership, structures, infrastructure as well as linguistic codes and cultural expression. Coloniality is defined as the residual structural and cultural presence of colonisation - such as mental, emotional, and agential dispositions and states of being - long after colonisers have left. These are evident in remnants of colonisation which include artefacts and other cultural signifiers that have meaning beyond their historical status such as statues, paintings and buildings (Grosfoguel 2007: 219).

Using coloniality as the denominator, decolonisation and decoloniality refer to the act of delinking (Mignolo 2007) from coloniality, to enable an unlearning of colonial dispositions, attitudes and beliefs that keep people entrapped and mentally enslaved. The prefix 'de', in de-colonisation and de-coloniality, is described as a decolonial gesture or delinking to strip coloniality of its power to suppress and oppress. Decoloniality is thus an active process of delinking from the colonial matrix of power by undoing the associated values and actions that were instilled by the colonial regime. Dastile \& Ndlovu-Gatsheni (2013) refer to decoloniality as a political and epistemic project of ex-colonised people.

Historically silenced voices are brought into the spotlight to foreground the value of plurality, multiplicity and difference, especially in an African context (Dastile \& Ndlovu-Gatsheni 2013). This act of foregrounding is coherent with the African philosophy and ontology of Ubuntu, which is referenced here not as a reified and romanticised concept, but as a relational concept that connects the parts, namely individuals, to the whole, which in this case is the community (Ramose, 2019).

In this paper we focus on the interrelation between coloniality and decoloniality, which are in dialectical tension with each other. By representing this relationship as (de)coloniality, we can explore how the metaphors of knowledge, being and power work by recognising oppression and then by drawing attention to the delinking aspects of this movement. We then explore disruption and delinking as catalyst and agency respectively, as necessary decolonial gestures to recast traditional curricula, pedagogy and assessments as transformed approaches to higher education. 


\section{CONCEPTUAL TOOLS}

The (de)coloniality of knowledge is concerned with asserting the position that multiple sources of knowledge that go beyond observation and reasoning, are important considerations in decolonial scholarship. Intuition or a 'gut-feel', for example, based on personal and professional experience and lived reality, is understood and experienced at a deep visceral level by indigenous people and should be counted as an important and legitimate source of knowledge production and construction. This 'non-empirical' knowledge is relevant, in this study, to the decolonial courses that participants designed, while also describing the knowledge shared by facilitators. In asserting these and other forms of legitimate knowledge, decoloniality is concerned with a construction of knowledge that does not render people invisible. The decolonial project is also concerned with reclaiming full visibility and authenticity for knowledge producers who are not located in the global North (Mamdani 2015). This is achieved by a process understood as 'epistemic disobedience' (Mignolo 2011), which is a necessary device for disrupting taken-for-granted assumptions about knowledge and its creation.

By understanding the historicity of disciplinary knowledges - as we did in the Understanding Decoloniality course, for example - we acknowledged that bodies of knowledge, as well as their epistemic traditions, became 'disciplined' as they travelled from one part of the world to another (Garuba 2017). As such, some were embellished while others had significant parts of their corpus and traditions excised or lost. The decoloniality of knowledge focuses on what counts as knowledge and whose interests it serves. Attached to this is the notion of epistemic justice and injustice (Fricker 2007). Through a decolonial lens, traditional and indigenous knowledges, often seen as inferior and thus subjugated through coloniality, are ushered in from the proverbial wings to take centre stage in collaborative knowledge construction and production processes (Molefe 2016). This erasure of indigenous knowledge, known as 'epistemicide' (De Sousa Santos 2007), created the 'Other' at the periphery, whose knowledges were located at the periphery.

The (de)coloniality of being is concerned with re-inserting the full humanity of people as thinking, feeling and doing individuals in a collective (Behari-Leak \& Mokou 2019). By reclaiming humans as full beings, irrespective of race, gender, ability, religion and so on, the decoloniality of Being brings attention to what it means to be human, who is seen to be human and what it takes to be in the 'Zone of 
Being' (Grosfoguel 2007). The (de)coloniality of being asserts that we are all capable of contributing as worthy and knowledgeable people who can exercise our powers as human beings in ways that advance our projects and commitments (Biko 1978). It is about creating a new imagination around who black people are and revoking the effects of the colonial subject who denies her own existence in the quest to emulate and mimic the coloniser in order to be recognised.

The (de)coloniality of power refers to undoing the colonial matrix of power where unequal nation states determined the quality and materiality of lives of subjects and citizens. The decoloniality of power is concerned with a new alignment of power between those in power because of class and other circumstances, and those who are powerless to effect change in their own lives. Power has significant consequences for a person's sense of self and their ability for self-determination and self-reliance. The decoloniality of power is concerned with how one's sense of diminished or augmented power limits or increases the actualisation of one's potential through awareness and consciousness as full beings. The decoloniality of power challenges us to remain vigilant about how we sustain dominant practices through what we do in our everyday, common-sense activities and dispositions. Hierarchies and heterarchies of power (Grosfoguel 2007) abound in higher education through careful reproduction of traditional and canonical curricula that do not consider epistemic plurality and do not use multiple lenses to assess critically how disciplines serve specific interests.

\section{METHODOLOGY}

\section{Generating the data}

Drawing on our experiences of the Understanding Decoloniality course discussed earlier, we used an auto-ethnographic approach to reflect critically on the course through narrative reflections generated by the two course convenors and two of the course participants. These narratives constitute the primary data that we analysed. The team decided to write their initial narrative reflections in response to four questions:

1. What were your explicit and implicit intentions in attending the course?

2. What were your experiences during the course?

3. What shifts occurred for you during the course, if any? 
4. What insights have you gleaned after being involved in the course?

The questions were formulated so that they allowed or enabled participants of the study to reflect on the concept of disruption, which is central to this paper. The first question was intended to prompt the participants to think about what they had hoped to gain from taking part in the course, largely driven by an awareness that there was something in their experiences within the academy that they had hoped would be changed by attending the course. The second question sought to give the researchers a chance to reflect on what they had experienced as possible disruptions, which linked to the third question of the shifts that had happened. The liminal space between experiences and shifts comprises the central space of disruption that the paper explores. The fourth question sought to give the researchers a chance to reflect on whether the shifts that they had experienced were commensurate with their expectations of the course and the extent to which their intentions coming in, articulated in the first question, were realised on their exit.

\section{Nested, layered analysis}

The analytical framework used in this study was key to uncovering the different and systematic layers of reflection that participants engaged in. Reflections are usually nested in each other, asynchronously and in a stream of reflective consciousness based on how the interlocutor responds to reflective prompts. These reflections are separated here for the purpose of analysis and interrogation. This method of analysis, known as analytical dualism (Archer 2000), is used carefully to separate layers and then bring them back together again to present a holistic view of participants' reality.

\section{First-level analysis}

After writing up our individual reflective narratives, we began with the first-level analysis by discussing the key codes or ideas that had emerged from our reflections. The discussion helped to immerse us in the data to aid the process of identifying commonalities and differences. Three key sites of disruption emerged across the four narrative reflections, each defining the researcher as someone who wears multiple hats in this study. 


\section{Sites of disruption}

1. Disruption of the researchers as self or person.

2. Disruption of the researchers as teachers within the academy.

3. Disruption of researchers as specialists within their respective disciplines.

In terms of the first site of disruption, the reflections that spoke to this theme revolved around the ways in which the researchers' overall outlook was influenced as a result of the course. The second disruption was experienced around their teacherhood and referred to those experiences during the course where the view of their position and place as lecturers within the academy was disrupted. The final site of disruption, of researchers' roles as specialists in a discipline, referred to the experiences during the course that changed their way of viewing their respective disciplines as a result of being exposed to how these disciplines and fields espoused coloniality. Thus, the first level of analysis employed was semantic and thematic analysis informed by these three sites of disruption (Braun \& Clarke 2006). The purpose of this first level of textual analysis was to focus the individual narratives which, until that point, were just responses to the four questions mentioned above. By focusing on three key sites of disruption, the researchers were able to home in on the most pertinent aspects to be analysed as part of the second level of analysis, which was a discourse analysis.

\section{Second-level analysis}

Bearing in mind that the aim of the study was to explore disruptions of coloniality experienced by academics who were part of a course on decoloniality, the second level of analysis employed critical discourse analysis (CDA) to ascertain not just what these academics had to say in the narratives that they wrote up, but how they said it, by looking at how language was used (Fairclough 1992). Critical discourse analysis is a multi-disciplinary approach that sees 'discourse' as a form of social practice that shapes social events and is also shaped by them (Chouliaraki \& Fairclough 1999). CDA aims to investigate social inequality as it is expressed, constituted and legitimised by language use (or in discourse). The importance of the text in relation to its context is what distinguishes discourse analysts from critical discourse analysts (Fairclough, Jessop \& Sayer 2004). In a realist sense, discourses are seen as generative mechanisms of the various dimensions of social life, including physical, chemical, 
biological, economic, social, psychological, linguistic and chemical, possessing distinct structures which affect the experiences of agents (Fairclough 2010). The 'critical' in CDA analyses language as a social practice through the lens of concepts such as power, ideology, discrimination, dominance, control and explores how these are manifested in language. The 'critical' aspect also refers to the ways in which identifying discourses allows us 'to question arguments or prevailing ideas' (Fairclough Jessop \& Sayer 2004). The overriding objective in using CDA is to give precise accounts of social change by looking at the ways in, and extent to, which social events are produced through discourse (Fairclough 2005).

To guide the second-level analysis, three aspects were considered in relation to how the narratives were written:

1. How they articulated the way the course served as a mechanism for disrupting coloniality.

2. How they articulated the ways in which this disruption was mediated.

3. How they articulated the ways in which the course enabled agency.

These three questions guided the way in which the second-level analysis was done. Quotes from the data were selected based on their relevance to the theoretical and conceptual framework that the study has used, namely the metaphors of (de) coloniality and nuanced with substantive links to decolonial scholarship on this topic. In terms of ethical considerations, all four participants are co-authors of this study and no ethical clearance was needed.

\section{DISCUSSION OF LAYERED ANALYSIS}

The layered analysis is presented here and discussed in relation to the central aims of the research study. As we engaged with each metaphor of coloniality, we brought in two layers of analysis, namely disruption of each metaphor and delinking from this metaphor, as shown below. 


\section{Disrupting the coloniality of knowledge}

\section{Colonial ways of knowing in the disciplines}

When we looked at midwifery and journalism and how this course worked with knowledge to disrupt internalised and normalised ways of doing and being in the disciplines, we brought into consciousness the way epistemology has worked in academia to frame the way the knowledge-project is shaped. Participants shared examples from their own courses and programmes and commented on the skewed representation in favour of epistemes and literature that are not from Africa or the global South. We started by looking at midwifery as a field of medical science where it soon became clear that the shaping of the content and knowledge has been done from a global North and Western perspective. In relation to knowledge-selection and -shaping in midwifery, participant 2 notes that,

with fourteen years of experience in both clinical (sic) and academia, it has become evident that there are two distinctly separate systems of birth which exist - one, based on the biomedical model, and the other focused in community-based, holistic, women-centred care. Overlaps between the two systems exist, but the domination of the biomedical model makes true holistic care seem dangerous.

\section{Colonial ways of knowing in midwifery}

Colonial medical education and knowledge was driven and managed by white, male bodies, and as doctors, who ensured that the local population (supposedly unknowing and unsuspecting) remained subordinate and domesticated. During the 17 th century in Europe, the missionary work of the West increased with a focus on spreading the Christian religion and civilised values throughout the 'heathen/uncivilised' world. At the same time, the Christian-led colonisation efforts were succeeding, but lacked the personnel to further the agenda (Heinsohn \& Steiger 2004). As a counter-narrative to this epistemically powerful knowledge-base, midwives at the time held, and freely shared, the knowledge of not only birth but also abortion and contraceptives. It is no coincidence that witch-hunts resurged with midwives as targets to erase the knowledge of abortion and contraception. This persecution was carried out so that a 
population explosion could occur to provide progeny to fuel the colonisation project overall (within Renaissance Europe) (Heinsohn \& Steiger 2004, page 22). These initiatives were led largely by the Catholic Church, as the dominant voice influencing the population, and was backed by the state which provided the manpower to conduct trials as well as executions. Although it is not clear exactly how many women were executed, it is clear that most towns and villages in Europe lost their midwives due to witch hunts (Heinsohn \& Steiger 2004). The words of Manfred Hammes, who documented the witch hunts that took place 17th-century Cologne, show the intensity with which midwives were hunted: 'In a period of intensive persecution (1627-1630), nearly all the town's midwives were extinguished. Every third of the executed women was a midwife, whereby their actual share may have been greater because in most of the cases the profession is not recorded in the files' (Hammes 1977: 62). As participant 1 notes,

this was the beginning of male-dominated medicine and ideology taking over birth - and the beginning of the coloniality of birthing bodies. Women, who actually gave birth were minimized in their contributions to this knowledge and much of what they knew was disregarded and reduced to myths and old wives' tales that had no place in the academy.

So, while many culturally-informed birthing processes are evident and in use by different indigenous communities, medical science as a discipline has historically legitimated and valued specific ways of 'doing science' that were rooted in western epistemologies and then in the coloniality of power and knowledge, steering midwifery into a mainly scientific domain, despite extant cultural and community practices that are different. The primary focus of traditional midwifery is to ensure that centre of birth stays with the woman, and provides an empowering space for birthing - which is opposite to power relations currently in facility-based birth. Here we see how the coloniality of power intersects with the coloniality of knowledge to promote a specific approach or methodology at the expense of indigenous knowledge.

\section{Colonial ways of knowing in journalism}

When we turned our attention to journalism as a field in the Humanities, we discussed the implications of epistemic justice and injustice in relation to how 
disciplines are controlled and 'disciplined. Through participant 2's reflective account on the epistemology of journalism, we witnessed how epistemic selection (power) shapes one's actions (doing) and sense of self (being) in a discipline. Existing internal tensions arise due to the colonial aspects of the discipline being in conflict and tension with embodied knowledge rooted in one's upbringing and socialisation through cultural processes:

During my eight years as a practicing journalist, I realised how the concepts that were ingrained into me in the course of my undergraduate studies, resulted in tensions between what I wanted to do based on my instinct and upbringing, versus what I was expected to do, based on the professional mandates I had been taught. Studying journalism disrupted me as a person by invalidating the knowledge I had, from my upbringing [...] knowledge on what it means to tell stories, and what kind of stories matter.

Within the context of working within one's own community, intuition or 'gut-feel', for example, based on personal and professional experience and lived reality, is understood and experienced at a deep visceral level by indigenous people but is not counted as legitimate or as an important source of knowledge production and construction in the academy. This often leads to erasure and misrecognition of indigenous communities and how they have survived and thrived over the years. When we enter the academy, the tacit if not explicit nudge is to leave cultural knowledge outside the classroom or laboratories, especially in the sciences, reinforcing the notion that scientific knowledge is far superior to any cultural knowledge on the same subject. An example of this can be evidenced in the ways in which academics and especially scientists responded to students who dared to ask whether there was room within the academy to consider phenomena such as lighting beyond the empirical evidence but within the discourses of spirituality and African cosmology.(Cameron, 2016) This was something that participants had to disrupt in themselves regarding how they come to the knowledge-project and what perceived powers they have to include and exclude knowledges that are central to their work. 


\section{Delinking from the coloniality of knowledge}

\section{Decolonial ways of knowing in the disciplines}

The coloniality of knowledge reminds us that we are sometimes complicit, knowingly or otherwise, in sustaining dominant epistemic practices through what we do in our everyday, common-sense activities and dispositions. The course urged participants to remain vigilant about their own engagement with disciplinary knowledge and how their perspectives and values were shaped by the colonial knowledge that had been reproduced as universal and value-free (Grosfoguel 2007). The course achieved this by asking participants to reflect on how the coloniality of knowledge, power and being were manifest in the disciplines/courses and their inherent practices.

As part of what they are taught, students come to privilege voices from certain institutions and authorities, such as government spokesperson (sic), $P R$ practitioners, academic scholars and experts as 'credible' sources of news, while voices of ordinary people, even if they are experts on their own lives, often need to be supplemented by other sources in order to be deemed credible. At the time of the early black press the voices that would be deemed as credible sources, such as officials and those in authority were not credible because they were speaking in support of apartheid. [The news reports from these vernacular language newspapers] then had to use sources and attribution in ways that aren't being taught as a mainstream approach to journalism. The journalists also couldn't rely on documented historical accounts to provide context because what was documented, for example with regard to land ownership, was not true. What was true were the oral accounts that were passed on within black communities. In how journalism is taught currently, those oral accounts might be described as hearsay, and would not be deemed as credible.

Decoloniality of knowledge privileges the role which people play in making sense of events around them and the practices which they engage in. It privileges experiential knowledge and personal histories and then also the tools, media through which such knowledge and histories are shared. To privilege oral traditions and the histories and knowledge that they carry is also to trust the source. Rather than regarding the 
speaker or holder of knowledge with skepticism, the decoloniality of knowledge does not necessitate that one need to have proven their expertise by degree qualification. Furthermore, the written record is always that of "the one who holds the swords." Within the decoloniality of knowledge what is written can always be disputed by that which has the lived experience.

\section{Disrupting the coloniality of power}

Reflecting on the objectives of the course and the intentions of the convenors, it was an explicit goal to disrupt the way participants interacted with each other and disciplinary knowledge. This was a move consciously to disrupt the power dynamics and assumptions about an 'all-knowing' teacher and 'blank slate' students. Invoking Freire's $(1970,2006)$ pedagogy of the oppressed, participants and facilitators engaged in non-hierarchical teaching strategies and participants were given ample space to insert and assert their own voice, beings, knowledge and reality. This meant that each session had to be structured differently to enable an ongoing bi-directional interplay between input and discussion, contrary to the unidirectional mode of transmission in the traditional classroom. Most sessions began with a question or activity that asked participants to reflect on and share their experiences, or possible understanding, of the topics to be covered in the session. Participant reflections were then followed by some input from the facilitator before giving the floor over to participants for questions. The second half of most sessions were characterised by group activities or discussions relating the topic to the experiences of the participants within the context of their disciplines or courses; facilitators took a back-seat and allowed the groups to work independently. All sessions ended in a plenary where participants would share the outcomes of their discussions or activities, field questions and ask questions of the facilitators. A facilitator reflects:

We sought to disrupt the banking model of education by choosing to facilitate a change process that reflected the concerns (and resources) of the participants in the room [...] by using praxis as a knowledge-making methodology. 


\section{Decolonial ways of enacting power in education spaces}

This emphasis on bringing participants in as co-creators of knowledge was also achieved by asking participants to reflect on their own courses and their own experiences and positionalities throughout the course and especially in their final assessments. Participants were invited to focus on how they could effect change in these domains. The course asserted that plural sources of knowledge that go beyond observation and reasoning (such as experiential knowledge) were important and critical to our work on this course, which brought together seventeen academics from a cross-spectrum of fields and disciplines in HE.

The first activity of the first session of the course brought participants into a circle to introduce themselves using a game. They were then asked to reflect and share on an artefact that they had brought to class that represented their first experience of coloniality. Rather than beginning in a traditional fashion where the convenors (standing in the front of the classroom) would have first introduced themselves and then the course before moving on to the contents of the course, this activity sought to dismantle traditional classroom dynamics and power relations. Furthermore, in later activities in that lesson, rather than providing a definition of coloniality and decoloniality, the participants were asked to share their understanding of these terms. As a co-convenor reflects, 'from this point on, we had activated their beings as the key domain from which to work rather than leading with theory as academics are prone to do. This de-centring of the discipline and the centring of the participant as the locus of experience, producer of knowledge and change-agent was an important delinking mechanism, to break with stereotypes and normative assumptions about where expertise resides and who can be regarded as a disciplinary expert.

Another activity in this first session asked participants to get into groups and reflect on the following questions: (1) Who is the ideal knower in my discipline/ course? and (2) who am I? By asking the participants to reflect on the relationship between the ideal knower and their own positionality and experience within the context of their discipline/course, the course succeeded in subverting the traditional power relations between discipline and knower by positioning the knower (i.e. the participant in the context of this course) as the authority and the locus of curriculum change (especially where their own disciplines/contexts were concerned).

Reflecting on participant l's own motives/objectives for taking the course, we see that the course enabled a re-alignment between how participants had 
experienced it and the cascading effects on their students. Participant 1 goes on: ' $[\mathrm{H}]$ ow I could provide a different experience for my students?' The emphasis here is on the participant as a change-agent and by placing the focus on the actions of the participant, we disrupt the coloniality of power and show the importance of individual and collective agency.

It is perhaps in these motivations and reflections that the course, within the immediate context of the classroom and disciplinary values and practices, sought to undo the colonial matrix of power (here located in the field of knowledge) where unequal stakeholders determine the quality and materiality of lives of subjects and citizens. By centring the students' experiences, participant 1 seeks to disrupt the coloniality of power that would make their students unequal partners (if not entirely invisible) in determining the quality and materiality of their classroom experiences. Furthermore, this participant's desire to bring in their student's prior knowledges and experiences into the classroom then opens up pluriversal ways of engaging with knowledge and the purpose it should serve, not only within the context of the classroom but also within the context of the society and communities from which their students come. As a start, participants needed to want to make a change and provide a different experience for their students, that is, an environment that recognised their difference as an asset to the co-creation of knowledge rather than expecting them to fit within the mould of the ideal knower.

\section{Delinking from the coloniality of power}

Another way in which the course sought to disrupt the coloniality of power and delink from coloniality was in the final learning outcome for Session 4, which was to expand the repertoire of academic knowledge to include knowledge generated in communities. In other words, the course challenged participants to think about where and when they could bring in significant knowledge from outside with the aim of making these knowledges legitimate, visible and representative of many of the students taking the course. After some input from the facilitator, participants were given an opportunity to get into groups (of disciplinary/course similarity) and brainstorm on ways in which they could meaningfully collaborate with communities outside of the academy. Facilitator 2 reflects that a key learning outcome for this session was that 'participants ought to be able to critically reflect on the ways they can partner with communities through their practices'. 
This specific learning outcome created the necessary conditions for participants to exercise their agency in ways that broke with the traditional knowledge- and knower-relations in their disciplines. One of the participants applied this learning outcome to her course to generate alternative perspectives on how midwifery could be taught and learnt. She goes on to reflect:

I want to include new knowledge of birthing bodies with the community in a way which does not rely on the biomedical model. This will be done through storytelling by bringing birth mothers [sic] into the class, which in and of itself is an alternate method of knowledge generation. Telling the story of their birthing bodies within the classroom will bring the community into the academy and generate new forms of knowing and doing. This will decrease or remove the silos of knowledge between the community and the academy.

\section{Decolonial ways of enacting power in the academy}

Not only does our egalitarian approach disrupt the traditional power relations within the coloniality of power and knowledge but delinks from coloniality by bringing in alternative ways of working with disciplinary knowledge. It does this by using popular and often marginalised, non-academic practices/methodologies to reposition the community (outside of the academy) as a site of knowledge-making. It furthermore allows the community (and the student) to re-emerge as an authority rather than only the academy/discipline. This mediation (the decoloniality of power) is concerned with a new alignment of power between those in power, through class, material and other circumstances, and those who are seemingly powerless to effect change in their own lives by allowing for what we could call communal agency.

Within a decolonial framework, power has significant consequences not only for the community but also for a person's sense of self and their capacity for selfdetermination and self-reliance. A way in which the course sought to encourage selfdetermination and self-reliance and allow participants to locate their own agency (power) was in the way it required participants to locate themselves and bring their bodies into the room, with all aspects of their personal, academic and professional selves and experiences: 
first exposed to coloniality, not only helped me think back to my experiences, but through the session in class [sic], I saw how others had been exposed to notion [sic] in ways that are similar and different to mine. I felt affirmed, realising that my experience as a former journalism practitioner-turned academic, who felt a little out of place. [sic] Through seeing how pervasive coloniality has been, by hearing about other examples that I had not even considered, I was prompted to really introspect. (P1)

This popular methodology of using participants' experiences and narratives to unpack and reflect on abstract concepts prompts them to consider what the course enabled them to do. Reflecting on this aspect of the course, participant 2 observes the following:

Firstly, it moved coloniality and decoloniality from being academic theories that were abstract to tangible experiences that have very real implications today. It moved these ideas from being 'tools' that people use to win academic debates, to being 'tools' that people use to either entrench a system or dismantle it in very practical ways. Secondly, it moved me forward in my quest to effect change in my discipline by giving me key sites where I could begin that process.

This resultant self-determination and self-reliance were realised through agency and praxis, key concepts in the course. Together they subvert the coloniality of power by locating the locus of change within the self rather than in the structure of the course alone. There is an understanding here that the structure is made/sustained by those who operate within it.

Added to this appreciation of agency, the decoloniality of power is also concerned with how one's sense of diminished or augmented power limits or increases the actualisation of one's potential through awareness and consciousness as a full being. Meaningful change cannot only occur at the intellectual level. Reflecting on the coloniality of knowledge, power and being as key concepts in the course, facilitator 1 observes:

[W]e also knew that decoloniality cannot be engaged with at only a knowledge level. We needed to foreground the decolonial being and enable participants to engage with what it means to 'be' differently, while acknowledging ways in 
which we had been socialised, colonised and 'normalised' into accepting the limitations of our own schooling and HE as well as when our beings confronted the ugliness of racism, sexism, classicism, ageism, etc. We also know that to disrupt our colonised sensibilities, we need to ground the course in Being while working with two other frames, Knowledge and Power.

Reflecting on the relationship between the academy and community as manifest in the personhood of the participant/academic, facilitator 2 reflects that the course delinked itself from colonial power by giving voice and space for disciplinary work to matter beyond the confines of the academy, thereby collapsing the walls between insiders and outsiders in knowledge and meaning making. They go on:

First, we sought to disrupt the notion of the educator as being removed from the community. Elaborating further, there was an understanding/appreciation of the ways in which participants' practices mattered to the communities (outside of the discipline) from which they come or in which they live.

This quote further advances an understanding that the participants were interacting in the course and with each other as full beings. This disrupts the coloniality of power and knowledge which, with reference to Cartesian dualism, attributes knowledge/ truth to the mind (the world of thought, the academy) rather than the body (the world of experience, the community).

\section{Disrupting the coloniality of being}

The decoloniality of being is concerned with re-inserting the full humanity of people as thinking, feeling and doing individuals in a collective. (Fanon1986; Grosfoguel 2007). The way we tried to incorporate this aspect into the course was to conceptualise the ontological dispositions of the course along the lines of being human. Facilitator 1 explained earlier:

We needed to foreground the decolonial being and enable participants to engage with what it means to 'be' differently[...] while acknowledging ways 
in which we had been socialised, colonised and 'normalised' into accepting the limitations of our own schooling and HE as well as when our beings confronted the ugliness of racism, sexism, classicism, ageism, etc.

\section{Colonial ways of being in the disciplines}

Again, the being/personhood is at the centre of the knowledge-project in the university and serves as a potential site for disruption. The dialectical tension between personhood (outside of the discipline) and practitioner or the academic, raises further tensions regarding one's identity, positionality and intersectionality. Assimilating into coloniality as a strategic move or disrupting the colonial being produces an internal conflict that must be mediated, as participant 2 explains:

An example of this would be when I was assigned to cover a story involving the death of someone in a tragic manner. In these instances, I would be conflicted between respecting the relatives of that person during their time of mourning and grief by not invading their space at such a private time, and getting the best 'story' possible by using those very emotions to put together a piece that would be deemed to be the most newsworthy. I was not brought up to use people's pain as a story; I was brought up to believe that pain is a sacred and intimate experience that exposes the most fundamental aspects of a person. On the other hand, my formal journalism training, through my media studies degree, has taught me that the best news stories are those that draw on people's emotions because in that way, the audience can relate to what you are reporting on.

Such internal conflicts only emerge as conflicts if there is a tension between what one deems as necessary for change (e.g. emotional connection or disciplinary practice). Here the conflict between who one is and what one does (for a living, say) bump into each other in ways that are not easy to resolve. For many people working in conditions where coloniality is a dominant feature, there is little choice and often one chooses strategically to downplay one's own self and defer to the dominant ethos so that this internal conflict is controlled and not expressed as an external rupture. But this happens at great cost to the self as the alienation and misalignment produces a fractured colonial subject, unable to think and be with all parts of the whole. This 
affects levels of agency and the ability to transform not just the self, but colonial systems one is embedded in. When the authors reflected on why they elected to do this course, it seemed like the act to sign up was in itself an act of intentional and directed agency, as if signing up was a gesture to indicate one's internal motivation towards decolonising the self and one's praxis. As participant 1 reflects: 'I went into this course with the hope of firstly understanding why I had this conflict, and secondly how I could provide a different experience for my students'

On how they sought to bring about change in their courses, participants displayed a strong identification with an 'activist identity' where the teachers see themselves and their practice as not merely agential but critical and invested in social transformation. Some of these ideas were expressed by participants as intentions to change the status quo in their disciplines:

[M]y students were introduced to the fact that journalism is a means of speaking truth to power, a way to give a voice to the voiceless, and should be driven by objective, unbiased and truthful accounts of contemporary events. At the face of it, there is nothing wrong with this[;] however, if this is the only view of journalism and society that students are exposed to, which I argue they are, then they are not being afforded an opportunity to shape their professional identities in other ways, such as journalists are social activists [sic] who lobby for change in their community, or journalists as facilitators of conversation who do not approach their stories as disinterested objective informants, but as affected subjects.

\section{Decolonial ways of being in the disciplines}

The decoloniality of being seeks to re-assert and re-affirm the notion that we are all capable of contributing as worthy and knowledgeable interlocutors who can exercise our 'powers' as human beings in ways that advance our projects and commitments (Biko 1978). There is considerable interplay between what looks like separate constructs namely knowledge, being and power. In the quote below we see how being is also located in discussion about knowledge" Participant 1 earlier, problematising the illegitimate position which oral histories and discourses hold within the context of journalism, suggests a repositioning and seeks to reaffirm the legitimacy of oral 
histories and discourses within the context journalism. They go on:

The journalists also couldn't rely on documented historical accounts to provide context because what was documented, for example with regard to land ownership, was not true. What was true were the oral accounts that were passed on within black communities. In how journalism is taught currently, those oral accounts might be described as hearsay, and would not be deemed as credible.

Finally, the decoloniality of being is concerned with the creation of a new imagination around who the colonised person is and with revoking the effects of the colonial subject who denies her existence in the quest to emulate and mimic the coloniser in order to be recognised. Conceptualising the course from this perspective, the convenors consciously and explicitly linked this new imagination to the sense of the academic self as both personal and social, inextricably linked to knowledge generation inside and beyond the university. The course encouraged participants to think beyond the confines of their disciplines in extensive and reflexive ways to see how and whether both domains of knowledge - within and outside of the university - can be co-created in the interest of a decolonial curriculum. Facilitator 1 reflects:

To ground the theory in context, we had decided to work with two main themes[,] namely academic and community activism. This also helped us to move between the silos of the academy and civics to disrupt the artificial borders and boundaries that kept the one side in and the other side out. The course was deliberately geared towards engaging participants in ways that drew on both dimensions and 'forced' them to think outside their institutional and disciplinary boundaries.

The course, therefore, sought to create a space where participants' concerns and experiences and the contexts within which they find themselves can be pulled together as resources for knowledge-making and transformation in terms of social and curricular change.

In this section we provided a description of the learning outcomes, teaching and learning activities, and assessment as evidence for our discussion. We also offered a 
critical discourse analysis of the narrative reflections of facilitators and participants in the Understanding Decoloniality course. With reference to journalism education, the discussion above shows how an approach informed by decoloniality can be used to identify the epistemic violence of colonial knowledge and colonial thought ingrained in the Western framework of practice that informs this field. Through the use of the metaphors of power, knowledge and being, the Understanding Decoloniality course provided a structure that allows the academic and her students to draw on other knowledge systems, such as those articulated in texts from the Early South African Black Press, to critique the neo-liberal power system that drives news media as a business; and to re-evaluate who is seen as a being or a non-being in the light of the Eurocentric values that currently characterise South African journalism (Tyali 2018; Pitcher \& Jones 2018).

With reference to midwifery education, the discussions in this paper show that the intentional epistemicide of traditional midwifery in the African context (carried over from practices carried out in Europe) has led to a reliance on the biomedical model of care. The purpose of the Understanding Decoloniality course was to serve as a site of disruption and a proposal to integrate and highlight Afrocentric health knowledge, power and being in a meaningful way in the teaching of midwifery in higher education. It has also served to realise the intersectionality of birthing bodies and re-centre birthing as an empowering process. This disruption would hopefully encourage the academic and student to examine the power and knowledge systems governing midwifery in order to embrace critical learning in a manner which is authentic and inclusive of indigenous knowledge systems.

Our engagement with the data surfaced particular issues, some at the level of pedagogical relations and others at the level of disciplinary relations. A key issue in both instances was the relationship between pedagogical and disciplinary discourses and colonial discursive practices as they relate to power, knowledge and being. Using the metaphors of coloniality (power, knowledge and being), we considered the relationship between agency and the traditional ways of knowledge-making in order to disrupt the coloniality of power, knowledge and being within the context of the classroom. A key finding was the role that agency plays in disrupting colonial discursive practices. 


\section{CONCLUSIONS}

This study highlights the potential that exists for academics to engage in decoloniality as a mechanism for changing teaching and curriculum design so that they can be socially just and responsive. This study, however, does point to the limitations inherent in the systemic level in different institutions that are resistant and reluctant to change. The decolonial turn, as experienced in South African HE in 2015, provided an opportunity to redress wounds inherited from a colonial and apartheid past. Many institutions, however, still are reluctant to explore how decoloniality offers a rich and deep way to engage with epistemologies, ontologies and their concomitant hegemonic forces which continue to grip us in a colonial and conceptual vice. Epistemic injustice and inequality need to be addressed urgently but not without a deep analysis of how a coloniality of knowledge is reproduced through dominant epistemic traditions at the university that continue to affect students' and academics' sense of well-being and self-worth.

Universality of knowledge cannot be achieved in an unequal university, where theories, doctrines and tools that are suitable for a minority of privileged contexts, are applied generically to all - universally - as if specific contexts and subjectivities therein have little choice but to be subjected to this grand sense of universality that has little meaning for the alienated, marginalised and silent interlocutors in the academy. What is needed is an inclusive or pluriversal approach to knowledge. Knowledge and power are intricately intertwined and interlinked, and in many contexts, knowledge is power especially when that knowledge derives from the global North and finds expression in powerful ways to shape the lives of people in the global South.

The study also shows, through participants' reflection, that knowledge finds expression in the being and bodies of those engaged with change. Positionality, as understood and experienced in this study, is based on individual's class, race, gender and place in a hierarchy of power; and is a strong case for legitimate knowledge claims made by those who have been excluded from knowledge generation and processes that do not reflect an indigenous or grounded perspective in relation to lived realities. This does not mean that expertise is not valued or relevant but it shows that who we are and from where we speak (Moyo 2011) is the basis for making our way through the world, which though physically similar for all, has dire extremities of inequality in terms of access, resources and justice for many.

Participants' social identities or lived experiences can no longer be ignored as 
legitimate grounds for knowledge production and embodied knowledge claims. For too long, higher education has failed to acknowledge and value the experiences and knowledge that students bring regarding the social and natural world. This study asserts that courses can be decolonised in ways that integrate lived and experiential knowledge with the 'powerful' knowledge advocated by disciplines and industry.

Knowledge and being, when sourced from sites other than the culturally and epistemically dominant groups in the academy, can offer a way for power to be understood as something that is enacted in service of the public good, and not for individual benefits. Disrupting colonial forms of curriculum and course-work, as well as pedagogy, is a necessary intervention that makes apparent and in turn subverts canonical ways of reproducing disciplinary hierarchies and power.

\section{References}

Archer, M.S. (2000). Being Human: the Problem of Agency. Cambridge University Press

Biko, S. (1978). I write what I like. London: Bowerdean Press.

Behari-Leak, K. \& Mokou, G. (2019). Disrupting metaphors of coloniality to mediate social inclusion in the global south. International Journal of Academic Development, 24(2): 135-147. https://doi.org/10.1080/1360144X.2019.1594236

Braun, V. \& Clarke, V. (2006). Using thematic analysis in psychology. Qualitative research in psychology, 3(2): 77-101.

Cape Higher Education Consortium. (2019). Quality Teaching in Higher Education: Short courses in 2019. Retrieved May 15, 2021 from http://www.chec.ac.za/files/ CHEC\%20QTHE\%20PROGRAMME\%202019\%20Advance\%20Notice\%20 revise.pdf

Cameron, J. (2016). Science decolonisers "reprehensible", says top UCT scientist after watching THIS video. https://www.biznews.com/mailbox/2016/10/18/sciencedecolonisers-reprehensible-uct

Chouliaraki, L. \& Fairclough, N. (1999). Discourse in late modernity: Rethinking critical discourse analysis. Edinburgh: Edinburgh University Press.

Curriculum Change Working Group. (2018, June). Curriculum change framework. University of Cape Town. https://www.news.uct.ac.za/images/userfiles/ downloads/media/UCT-Curriculum-Change-Framework.pdf

Dastile, N.P. \& Ndlovu-Gatsheni, S. (2013). Power, knowledge and being: Decolonial 
combative discourse as a survival kit for pan-Africanists in the 21st Century. Alternation, 20(1): 105 - 134

Deacon, H. (1998). Midwives and medical men in the Cape colony before 1860. The Journal of African History, 39(2): 271-292.

Du Bois, W.E.B. (1999). The souls of black folk: Authoritative text, contexts, criticisms, eds. Henry Louis Gates Jr \& Terri Hume Oliver. New York: Norton.

Fairclough, N. (1992). Discourse and social change. Cambridge: Polity.

Fairclough, N., Jessop, B. \& Sayer, A. (2004). Critical realism and semiosis. In J. Joseph and J. Roberts (eds), Realism, discourse and deconstruction (pp. 23-42). London: Routledge.

Fairclough, N. (2005). Peripheral vision: Discourse analysis in organization studies: The case for critical realism. Organization Studies, 26: 915-939.

Fairclough, N. (2010). Critical discourse analysis (2nd edition). London: Longman.

Fanon, F. (1986). The wretched of the earth. New York: Grove Press.

Finlay, A. (2019) Newsroom in review, in A. Finlay (ed.), State of the newsroom 2018: Structured unstructured, Wits Journalism Project, viewed 02 November 2019, from https://journalism.co.za/wp-content/uploads/2019/07/State-of-theNewsroom-report-2018_updated-20190709.pdf.

Fricker, M. (2007). Epistemic injustice: Power and the ethics of knowing. Oxford: Oxford University Press.

Freire, P. (2006). Pedagogy of the oppressed. 30th Anniversary ed. New York: Continuum. Retrieved from http://schd.ws/hosted_files/2017udlsymposium/1d/ Pedgagogy\%20of\%20the\%20Oppressed.pdf

Garuba, H. (2017). Travelling disciplines and the Global South. Paper presented at the English Academy Conference, Granger Bay, South Africa.

Gordon, L. (2019). Black aesthetics, black value, and challenges of liberation and political life. Paper presented at the Unisa Decoloniality Summer School, Pretoria, South Africa.

Grosfoguel, R. (2007). The epistemic decolonial turn: Beyond political-economy paradigms. Cultural Studies, 21(2/3): 211-223.

Heinsohn, G. \& Steiger, O. (2004). Witchcraft, population catastrophe and economic crisis in Renaissance Europe: An alternative macroeconomic explanation. Issue 29 of IKSF discussion paper. Bremen: Institut für Konjunktur- und Strukturforschung. Hammes, M. (1977). Hexenwahn und Hexenprozesse. Frankfurt am Main: S. Fischer. Kessi, S. (2017). Community social psychologies for decoloniality: An African 
perspective on epistemic justice in higher education. South African Journal of Psychology, 47(4), 506-516.

Maldonado-Torres, N. (2007). On the coloniality of Being: Contributions to the development of a concept. Cultural Studies, 21(2/3): 240-270.

Maldonado-Torres, N. (2016). Outline of ten theses on coloniality and decoloniality (pp. 26-28). Paris: Frantz Fanon Foundation.

Mamdani, M. (2016). Between the public intellectual and the scholar: Decolonization and some post-independence initiatives in African higher education. Inter-Asia Cultural Studies, 17(1):68-83. https://doi.org/10.1080/14649373.2016.1140260

Mampane, R.M., Omidire, F.M. \& Aluko, F.R. (2018). Decolonising higher education in Africa: Arriving at a global solution. South African Journal of Education, 38(1636) 9.

Maserumule, M.H. (2015, 25 November). Why Africa's professors are afraid of colonial education being dismantled. The Conversation. https://theconversation.com/whyafricas-professors-are-afraid-of-colonial-education-being-dismantled-50930.

Mbembe, A. (2016). Transformation/Decolonization at Wits. (Facebook post). Available at https://www.facebook.com/achille.mbembe/ posts/10153057656896451 [accessed 30 August 2016].

Mignolo, W. D. (2007). Delinking: The rhetoric of modernity, the logic of coloniality and the grammar of de-coloniality. Cultural Studies, 21(2/3): 449-514. https://doi. org/10.1080/09502380601162647

Mignolo, W. D. (2011). Epistemic disobedience and the decolonial option: A manifesto. Transmodernity: Journal of Peripheral Cultural Production of the LusoHispanic World, 1(2): 44-67.

Mkhize, N. (2015, 7 April). Anger over Rhodes vindicates Mamdani. Business Day. http://www.bdlive.co.za/opinion/columnists/2015/04/07/anger-over-rhodesvindicates-mamdani

Molefe, T.O. (2016). Oppression Must Fall: South Africa's revolution in theory. World Policy Journal 33(1): 30-37.

Moyo, $\mathrm{P}$.

Pillay, S. (2015, June). Decolonising the university. Africa is a Country. http:// africasacountry.com/2015/06/decolonizing-the-university/.

Pitcher, S., \& Jones, N. (2018). Decolonising \& Africanising: Discussing Current Challenges of Curriculum Development in a South African University Journalism Programme. In Conference Proceedings. The Future of Education (p. 369). 
libreriauniversitaria. it Edizioni.

Ramose, M. (2019). A philosophical investigation into the conceptual history of decolonisation in Africa. Paper presented at the Unisa Decoloniality Summer School, Pretoria, South Africa.

Salawu, A. (2013). Stunted growth: An exploration into the failures of Africanlanguage newspapers, Imvo Zabantsundu in focus. Ecquid Novi: African Journalism Studies, 34(2), 73-92.

Santos, B. de S. (2007). Beyond abyssal thinking: From global lines to ecologies of knowledges. Review, 30(1): 45-89.

Spivak, G. C. (1994). The post-colonial critic, interviews, strategies, dialogues. London: Routledge.

Tyali, S. M. (2018). Ambiguities of a decolonising press culture: on South Africa's Imvo Zabantsundu (Native Opinion). South African Journal of African Languages, 38(3), 303-309.

\section{Bibliography}

Cape Higher Education Consortium. (2019). Quality Teaching in Higher Education: Short courses in 2019. Retrieved May 15, 2021 from http://www.chec.ac.za/files/ CHEC\%20QTHE\%20PROGRAMME\%202019\%20Advance\%20Notice\%20 revise.pdf 